\title{
Molecular Assembly and Micellization of Molybdenum(V, IV) Thiolate and Selenolate Complexes with Long Hydrocarbon Chains
}

\author{
Taka-aki OKamura, Kaku TaniUchi, Norikazu Ueyama, ${ }^{\dagger}$ \\ and Akira NAKAMURA ${ }^{\dagger}$ \\ Department of Macromolecular Science, Graduate School of Science, Osaka University, \\ Toyonaka, Osaka 560-0043, Japan
}

(Received December 21, 1998)

\begin{abstract}
Molybdenum(IV, V) thiolate and selenolate complex with four long bundling hydrocarbon chains connected to the amide group, $\left(\mathrm{Ph}_{4} \mathrm{P}\right)\left[\mathrm{Mo}^{\mathrm{v}} \mathrm{O}\left\{\mathrm{S}-2-\mathrm{CH}_{3}\left(\mathrm{CH}_{2}\right)_{10} \mathrm{CONHC}_{6} \mathrm{H}_{4}\right\}_{4}\right]$ and $\left(\mathrm{NEt}_{4}\right)_{2}\left[\mathrm{Mo}{ }^{\mathrm{IV}} \mathrm{O}\left\{\mathrm{Se}-2-\mathrm{CH}_{3}\left(\mathrm{CH}_{2}\right)_{10} \mathrm{CONHC}_{6} \mathrm{H}_{4}\right\}_{4}\right]$ were synthesized. The four chains are oriented toward the same direction in the solution as established by ${ }^{1} \mathrm{H}$ NMR. These complexes were soluble in an aqueous micellar solution and stabilized against hydrolysis in such aqueous media efficiently by the hydrocarbon chains. The preliminary results of X-ray analysis revealed the individual molecular assembly behavior which depends significantly on the oxidation state of metal ion and the kind of coordinated atom.

KEY WORDS Micellization / Hydrocarbon Chain / Assembly / Molybdenum Complex /
\end{abstract}

From a biological point of view, bundling polypeptides or hydrocarbon chains with the same orientation are interesting models for a protein folding, the active site of enzymes, and molecular recognition in biomembrane. ${ }^{1-4}$ Previously, we reported molybdenum(V) and molybdenum(IV) complexes containing oriented four acetylamino groups, $\left(\mathrm{NEt}_{4}\right)\left[\mathrm{Mo}^{\mathrm{V}} \mathrm{O}\left(\mathrm{S}-2-\mathrm{CH}_{3} \mathrm{CO}\right.\right.$ $\left.\left.\mathrm{NHC}_{6} \mathrm{H}_{4}\right)_{4}\right]$ and $\left(\mathrm{NEt}_{4}\right)_{2}\left[\mathrm{Mo}^{\text {IV }} \mathrm{O}\left(\mathrm{S}-2-\mathrm{CH}_{3} \mathrm{CONHC}_{6}\right.\right.$ $\left.\mathrm{H}_{4}\right)_{4}$, whose structure allows unique opportunity to bundle four long hydrocarbon chains on the acetyl groups. ${ }^{5}$ Replacement of sulfur by selenium gave isostructual molecule due to their similar chemical properties. The $\mathrm{MoOQ}_{4}(\mathrm{Q}=\mathrm{S}, \mathrm{Se})$ core has a potential flexibility depending on the oxidation state of metal ion and a kind of $\mathrm{Q}$ which determines distance and character of the Mo-Q bonds. Furthermore some biological activities are considered to be supported in hydrophobic media. To simulate biological hydrophobic environment, ones have used hydrophobic solvents, e.g., chloroform, or aqueous micellar solution where the micelles exclude bulk water and hydrogen bond is supported inside of the hydrophobic micelles. ${ }^{6}$ Our complexes with hydrocarbon chains can possess a good affinity to both hydrophobic solvents and micelles.

On the other hand, three dimensional construction of molecules or supramolecular structure is one of the most noteworthy problems. Especially, supramolecules involving metal ion have been synthesized for their unique physical properties. An ordered orientation of layered molecules in the solid state leads to interesting electronic and magnetic properties. ${ }^{7-9}$ Many of the known such supramolecules exist as assemblies of molecules having two dimensional spread and/or long linear hydrocarbon chains perpendicular to a disk-shape molecule, e.g., porphyrin. ${ }^{10-13}$ Some molecules having bent structure ${ }^{14}$ or radial chains ${ }^{15}$ have also been reported. Although many kinds of molecules have been known, these molecules have a rigid structure connecting hydrocarbon chains. We have tried to design novel molecules containing flexible basic structure for developing a new type of supramolecule.

In this paper, the structures of molybdenum(V, IV) complexes containing long hydrocarbon chains with specific intermolecular assembly are described. Formation and the stability of a micellar solution and properties of the complexes are also reported.

\section{EXPERIMENTAL}

\section{Materials}

All procedures were performed in argon atmosphere by the Schlenk technique. All solvents were dried and distilled under argon before use. Bis(2-aminophenyl) diselenide was prepared by the reported method. ${ }^{16}$ $\left(\mathrm{NEt}_{4}\right)\left[\mathrm{Mo}^{\mathrm{v}} \mathrm{O}(\mathrm{SPh})_{4}\right]$ and $\left(\mathrm{PPh}_{4}\right)\left[\mathrm{Mo}^{\mathrm{v}} \mathrm{O}(\mathrm{SPh})_{4}\right]$ were synthesized by the reported method. ${ }^{17}$

\section{Bis(2-lauroylaminophenyl) Disulfide, $\left\{\mathrm{S}-2-\mathrm{CH}_{3}\left(\mathrm{CH}_{2}\right)_{10}\right.$ $\left.\mathrm{CONHC}_{6} \mathrm{H}_{4}\right\}_{2}$}

To a tetrahydrofuran (THF) solution $(10 \mathrm{~mL})$ of lauric acid $(4.0 \mathrm{~g}, 20 \mathrm{mmol})$ was added thionyl chloride $(3 \mathrm{~mL}$, $40 \mathrm{mmol}$ ). After refluxing for $1 \mathrm{~h}$, the reaction mixture was concentrated in vacuo. The resulting oily residue which was lauroyl chloride, was used for synthesis without further purification. To a THF solution $(30 \mathrm{~mL})$ of $2,2^{\prime}$-dithiodianiline $(2.5 \mathrm{~g}, 10 \mathrm{mmol})$ was added pyridine $(10 \mathrm{~mL})$ and lauroyl chloride $(4.2 \mathrm{~g}, 20 \mathrm{mmol})$ at $0^{\circ} \mathrm{C}$ and refluxed for $2 \mathrm{~h}$. Removal of solvent gave pale yellow solid. After addition of water, the solid was collected with filtration, washed with successive water, $\mathrm{NH}_{3}$ aq, water, $2 \% \mathrm{HCl}$ aq, and water. The crude product was dissolved in hot ethanol and left at room temperature to give white crystalline solid, which was collected with filtration, washed with cold ethanol and dried in vacuo over $\mathrm{P}_{2} \mathrm{O}_{5}$. Yield $3.0 \mathrm{~g}(49 \%)$. ${ }^{1} \mathrm{H}$ NMR (chloroform- $\left.d_{1}\right)$; $\delta 0.88(\mathrm{t} 6 \mathrm{H}), 1.27(\mathrm{~m}(\mathrm{br}) 32 \mathrm{H}), 1.61(\mathrm{~m} 4 \mathrm{H}), 2.16(\mathrm{t}$ $4 \mathrm{H}), 6.99$ (t 2H), 7.39 (m 4H), 7.96 (s $2 \mathrm{H}), 8.40$ (d 2H). Anal. Calcd for $\mathrm{C}_{36} \mathrm{H}_{56} \mathrm{~N}_{2} \mathrm{O}_{2} \mathrm{~S}_{2}$ : C, $70.54 \% ; \mathrm{H}, 9.21 \%$; N, $4.57 \%$. Found: C, 70.29\%; H, 9.15\%; N, 4.54\%.

\footnotetext{
† To whom correspondence should be addressed.
} 
Bis [2-(8-pentadecanecarbonylamino)phenyl $]$ Disulfide $[S$ $\left.2-\mathrm{CH}_{3}\left(\mathrm{CH}_{2}\right)_{8}\left\{\mathrm{CH}_{3}\left(\mathrm{CH}_{2}\right)_{6}\right\} \mathrm{CHCONHC}_{6} \mathrm{H}_{4}\right]_{2}$

The compound was synthesized by the same method described above. White solid was obtained in $61 \%$ yield. ${ }^{1} \mathrm{H}$ NMR (chloroform- $d_{1}$ ); $\delta 0.86$ (t 12H), 1.27 (m (br) $48 \mathrm{H}), 1.50(\mathrm{~m} 4 \mathrm{H}), 1.63(\mathrm{~m} 4 \mathrm{H}), 2.11(\mathrm{~m} 2 \mathrm{H}), 6.94$ (t 2H), 7.18 (d 2H), 7.40 (t 2H), 8.07 (s $2 \mathrm{H}), 8.44$ (d $2 \mathrm{H})$. Anal. Calcd for $\mathrm{C}_{48} \mathrm{H}_{80} \mathrm{~N}_{2} \mathrm{O}_{2} \mathrm{~S}_{2}: \mathrm{C}, 73.79 \% ; \mathrm{H}$, $10.32 \%$; N, 3.59\%. Found: C, $73.77 \% ; \mathrm{H}, 10.30 \%$; $3.57 \%$.

\section{Bis(2-lauroylaminophenyl) Diselenide, $\left\{\mathrm{Se}-2-\mathrm{CH}_{3}\left(\mathrm{CH}_{2}\right)_{10}\right.$ $\left.\mathrm{CONHC}_{6} \mathrm{H}_{4}\right\}_{2}$}

To a THF solution $(30 \mathrm{~mL})$ of bis(2-aminophenyl) diselenide $(1.4 \mathrm{~g}, 4.1 \mathrm{mmol})$ containing pyridine $(1 \mathrm{~mL})$ was added lauroyl chloride $(2.2 \mathrm{~g}, 10 \mathrm{mmol})$ at $0^{\circ} \mathrm{C}$ and refluxed for $2 \mathrm{~h}$. Removal of solvent gave yellow solid. After addition of water $(150 \mathrm{~mL})$, the suspension was extracted with ethyl acetate $(200 \mathrm{~mL})$. The obtained organic layer was washed with water, $2 \% \mathrm{HCl}$ aq, water, $4 \% \mathrm{NaHCO}_{3}$ aq, water and sat. $\mathrm{NaCl}$ aq, successively. The orange solution was dried over sodium sulfate and concentrated under reduced pressure to give orange solid. The crude product was recrystallized from hot $n$-hexane to give pale yellow crystalline solid, which was collected with filtration, washed with cold $n$-hexane and dried in vacuo. Yield $1.5 \mathrm{~g}(51 \%)$. Anal. Calcd for $\mathrm{C}_{36} \mathrm{H}_{56}$ $\mathrm{N}_{2} \mathrm{O}_{2} \mathrm{Se}_{2}: \mathrm{C}, 61.18 \% ; \mathrm{H}, 7.99 \% ; \mathrm{N}, 3.96 \%$. Found: C, $61.34 \% ; \mathrm{H}, 8.10 \%$; N $3.78 \%$.

\section{$\left(\mathrm{NEt}_{4}\right)\left[\mathrm{Mo}^{\mathrm{v}} \mathrm{O}\left\{\mathrm{S}-2-\mathrm{CH}_{3}\left(\mathrm{CH}_{2}\right)_{10} \mathrm{CONHC}_{6} \mathrm{H}_{4}\right\}_{4}\right]$ (1)}

A mixture of $\left\{\mathrm{S}-2-\mathrm{CH}_{3}\left(\mathrm{CH}_{2}\right)_{10} \mathrm{CONHC}_{6} \mathrm{H}_{4}\right\}_{2}(108$ $\left.\mathrm{mg}, 1.8 \times 10^{-4} \mathrm{~mol}\right)$ and $\left(\mathrm{NEt}_{4}\right)\left[\mathrm{Mo}^{\mathrm{v}} \mathrm{O}(\mathrm{SPh})_{4}\right](50 \mathrm{mg}$, $7.4 \times 10^{-5} \mathrm{~mol}$ ) was stirred in $5 \mathrm{~mL}$ of 1,2-dimethoxyethane (DME) overnight at room temperature. The obtained clear solution was concentrated to give oily materials. After addition of diethyl ether, the resulting microcrystals were collected by filtration which was washed by diethyl ether. Deep purple crystals were obtained by recrystallization from acetonitrile/diethyl ether. Yield $77 \mathrm{mg}(71 \%)$. Anal. Calcd for $\mathrm{C}_{80} \mathrm{H}_{132} \mathrm{~N}_{5}$ $\mathrm{O}_{5} \mathrm{~S}_{4} \mathrm{Mo}$ : C, $65.45 \%$; H, 9.06\%; N, 4.77\%. Found: $\mathrm{C}$, $65.05 \%$; H, $9.04 \%$; N, $4.79 \%$.

\section{$\left(\mathrm{Ph}_{4} \mathrm{P}\right)\left[\mathrm{Mo}^{\mathrm{v}} \mathrm{O}\left\{\mathrm{S}-2-\mathrm{CH}_{3}\left(\mathrm{CH}_{2}\right)_{10} \mathrm{CONHC}_{6} \mathrm{H}_{4}\right\}_{4}\right]\left(\mathbf{1}^{\prime}\right)$}

The complex was synthesized by the same method for the synthesis of 1 using the $\mathrm{PPh}_{4}^{+}$salt. Deep purple large thin plates were obtained from hot acetonitrile in $30 \%$ yield.

$\left(\mathrm{NEt}_{4}\right)_{2}\left[\mathrm{Mo}^{\mathrm{iv}} \mathrm{O}\left\{\mathrm{S}-2-\mathrm{CH}_{3}\left(\mathrm{CH}_{2}\right)_{10} \mathrm{CONHC}_{6} \mathrm{H}_{4}\right\}_{4}\right]$ (2)

To a DME solution of $1(330 \mathrm{mg}, 0.22 \mathrm{mmol})$ was added $\mathrm{NEt}_{4} \mathrm{BH}_{4}(40 \mathrm{mg}, 0.28 \mathrm{mmol})$. After stirring for $5 \mathrm{~h}$, precipitated solid was collected by filtration and washed with diethyl ether. The crude pale purple precipitate was recrystallized from acetonitrile/diethyl ether to give dark green plates. Yield $210 \mathrm{mg}(59 \%)$. Anal. Calcd for $\mathrm{C}_{88} \mathrm{H}_{152} \mathrm{~N}_{6} \mathrm{O}_{5} \mathrm{~S}_{4} \mathrm{Mo}$ : C, $66.13 \%$; H, 9.58\%; $\mathrm{N}, 5.26 \%$. Found: C, $65.66 \%$; H, 9.73\%; N, 5.64\%.

$\left(\mathrm{NEt}_{4}\right)_{2}\left[\mathrm{Mo} \mathrm{IV}^{\mathrm{OV}}\left\{\mathrm{S}-2-\mathrm{CH}_{3}\left(\mathrm{CH}_{2}\right)_{8}\left[\mathrm{CH}_{3}\left(\mathrm{CH}_{2}\right)_{6}\right] \mathrm{CHCO}\right.\right.$ $\left.\left.\mathrm{NHC}_{6} \mathrm{H}_{4}\right\}_{4}\right]$ (3)

A mixture of $\left(\mathrm{NEt}_{4}\right)\left[\mathrm{Mo}^{\mathrm{V}} \mathrm{O}(\mathrm{SPh})_{4}\right](130 \mathrm{mg}, 1.9 \times$ $\left.10^{-4} \mathrm{~mol}\right)$ and $\left\{\mathrm{S}-2-\mathrm{CH}_{3}\left(\mathrm{CH}_{2}\right)_{8}\left[\mathrm{CH}_{3}\left(\mathrm{CH}_{2}\right)_{6}\right] \mathrm{CHCON}\right.$ $\left.\mathrm{HC}_{6} \mathrm{H}_{4}\right\}_{2}\left(360 \mathrm{mg}, 4.6 \times 10^{-4} \mathrm{~mol}\right)$ in acetonitrile $(5 \mathrm{~mL})$ was stirred at $50^{\circ} \mathrm{C}$ for $2 \mathrm{~h}$. The solution was concentrated to give residual oil which was washed twice with $n$-hexane. The resultant product, $\left(\mathrm{NEt}_{4}\right)\left[\mathrm{Mo}^{\mathrm{v}} \mathrm{O}\left\{\mathrm{S}-2-\mathrm{CH}_{3}\left(\mathrm{CH}_{2}\right)_{8}\right.\right.$ $\left.\left.\left[\mathrm{CH}_{3}\left(\mathrm{CH}_{2}\right)_{6}\right] \mathrm{CHCONHC}{ }_{6} \mathrm{H}_{4}\right\}_{4}\right]$, was dissolved in $2 \mathrm{~mL}$ of DME and $\mathrm{NEt}_{4} \mathrm{BH}_{4}\left(34 \mathrm{mg}, 2.3 \times 10^{-4}\right)$ was added to the solution. After stirring overnight, red crystals were deposited which were collected by filtration and washed by diethyl ether. The crude product was purified by recrystallization from hot acetonitrile. Red plates were obtained in $34 \%$ yield based on $\left(\mathrm{NEt}_{4}\right)\left[\mathrm{Mo}^{\mathrm{v}} \mathrm{O}(\mathrm{SPh})_{4}\right]$. Anal. Calcd for $\mathrm{C}_{112} \mathrm{H}_{200} \mathrm{~N}_{6} \mathrm{O}_{5} \mathrm{~S}_{4} \mathrm{Mo}$ : C, $69.52 \%$; H, $10.42 \%$; N, $4.34 \%$. Found: C, $68.85 \% ; \mathrm{H}, 10.62 \%$; N, $4.32 \%$.

$\left(\mathrm{NEt}_{4}\right)_{2}\left[\mathrm{Mo}^{\mathrm{IV}} \mathrm{O}\left\{\mathrm{Se}-2-\mathrm{CH}_{3}\left(\mathrm{CH}_{2}\right)_{10} \mathrm{CONHC}_{6} \mathrm{H}_{4}\right\}_{4}\right]$ (4)

A mixture of $\left(\mathrm{NEt}_{4}\right)\left[\mathrm{Mo}^{\mathrm{v}} \mathrm{O}(\mathrm{SPh})_{4}\right](190 \mathrm{mg}, 0.27$ $\mathrm{mmol})$ and bis(2-lauroylaminophenyl) diselenide (610 $\mathrm{mg}, 0.86 \mathrm{mmol})$ in DME $(9 \mathrm{ml})$ was stirred at room temperature overnight. The solution was concentrated under reduced pressure to give oily material and washed with diethyl ether. After adding tetraethylammonium borohydride $(55 \mathrm{mg}, 0.38 \mathrm{mmol}$ ), the mixture in DME $(7 \mathrm{~mL})$ were stirred for $5 \mathrm{~h}$. The resulting precipitation was collected by filtration and washed with DME and diethyl ether. The crude powder was dissolved in $15 \mathrm{~mL}$ of acetonitrile and the solution was filtered to remove insoluble materials. The solution was concentrated under reduced pressure and the residue was recrystallized from hot acetonitrile to give purple-red plate. Yield $100 \mathrm{mg}$ (22\%). Anal. Calcd for $\mathrm{C}_{88} \mathrm{H}_{152} \mathrm{~N}_{6} \mathrm{O}_{5} \mathrm{Se}_{4} \mathrm{Mo}$ : C, $59.18 \%$; $\mathrm{H}, 8.58 \%$; N, $4.71 \%$. Found: C, $58.87 \%$; H, $8.59 \%$; N, $5.01 \%$.

\section{Preparation of Aqueous Micellar Solution of $\mathbf{1}$}

Compound $1\left(3.7 \mathrm{mg}, 2.5 \times 10^{-6} \mathrm{~mol}\right)$ was dissolved in a small amount of THF. To the solution was added $0.1 \mathrm{~mL}$ of Triton X-100 and concentrated under reduced pressure. The obtained viscous oil was diluted with $0.9 \mathrm{~mL}$ of water to give a homogeneous $2.5 \mathrm{mM}$ aqueous micellar solution. Another $0.25 \mathrm{mM}$ solution was prepared in the same way. The aqueous micellar solution did not bleach for 3 days on exposure to air.

\section{Preparation of Aqueous Micellar Solution of $\mathbf{4}$}

Each $2.5 \mathrm{mM}$ and $1.0 \mathrm{mM}$ aqueous micellar solution was prepared in the same way described for 1 except for using acetonitrile instead of THF.

\section{Hydrolysis Reactions of $\left(\mathrm{NEt}_{4}\right)\left[\mathrm{Mo}^{\mathrm{v}} \mathrm{O}\left(\mathrm{S}-2-\mathrm{RCONHC}_{6}\right.\right.$} $\left.\left.\mathrm{H}_{4}\right)_{4}\right]\left(\mathrm{R}=\mathrm{CH}_{3}, \mathrm{CH}_{3}\left(\mathrm{CH}_{2}\right)_{10}\right)$

To $1 \mathrm{mM}$ acetonitrile solution $(0.3 \mathrm{~mL})$ of $\left(\mathrm{NEt}_{4}\right)$ $\left[\mathrm{Mo}^{\mathrm{V}} \mathrm{O}\left(\mathrm{S}-2-\mathrm{RCONHC}_{6} \mathrm{H}_{4}\right)_{4}\right]\left(\mathrm{R}=\mathrm{CH}_{3}, \mathrm{CH}_{3}\left(\mathrm{CH}_{2}\right)_{10}\right)$ was added $0.03 \mathrm{~mL}$ of water in $1 \mathrm{~mm}$ cell under argon atmosphere at room temperature. The reaction was followed by the absorbance at $540 \mathrm{~nm}$ for $60 \mathrm{~min}$.

\section{Physical Measurements}

${ }^{1} \mathrm{H}$ NMR spectrum was recorded on a Jeol EX-270 and a Varian Unityplus $600 \mathrm{MHz}$ spectrometer in acetonitrile- $d_{3}$ solution at $30^{\circ} \mathrm{C}$. UV-visible spectra were taken on a Jasco Ubest-30. IR spectra were obtained on 
a Jasco FT/IR-3. Samples were prepared as $\mathrm{KBr}$ disk. Electrochemical measurements were performed using a Yanako P-1100 instrument and BAS $100 \mathrm{~B} / \mathrm{W}$ in $2.5 \mathrm{mM}$ solution containing $0.1 \mathrm{M}$ tetra- $n$-butylammonium perchlorate for an acetonitrile solution or tetraethyl ammonium chloride for an aqueous solution as supporting electrolyte. $E_{1 / 2}$ value, determined as $\left(E_{\mathrm{p}, \mathrm{a}}+E_{\mathrm{p}, \mathrm{c}}\right) / 2$, was referenced to the SCE electrode at room temperature.

\section{Preliminary $X$-Ray Analysis of $\mathbf{1}^{\prime}$ and $\mathbf{4}$}

Each single crystals of $\left(\mathrm{PPh}_{4}\right)\left[\mathrm{Mo}^{\mathrm{V}} \mathrm{O}\left\{\mathrm{S}-2-\mathrm{CH}_{3}\left(\mathrm{CH}_{2}\right)_{10}\right.\right.$ $\left.\left.\mathrm{CONHC}_{6} \mathrm{H}_{4}\right\}_{4}\right]\left(\mathbf{1}^{\prime}\right)\left(\mathrm{NEt}_{4}\right)_{2}\left[\mathrm{Mo}{ }^{\mathrm{IV}} \mathrm{O}\left\{\mathrm{Se}-\mathrm{O}-\mathrm{CH}_{3}\left(\mathrm{CH}_{2}\right)_{10}\right.\right.$ $\left.\left.\mathrm{CONHC}_{6} \mathrm{H}_{4}\right\}_{4}\right]$ (4) was sealed in a glass capillary under argon atmosphere. X-Ray measurement was performed at $23^{\circ} \mathrm{C}$ on a Rigaku AFC5R diffractometer with graphite monochromated Mo- $K_{\alpha}$ radiation. Unit cell dimensions, $a=17.83(4) \AA, b=31.60$ (3) $\AA, c=17.58(2) \AA, \quad \beta=91.0$ $(1)^{\circ}$, and $V=9900(25) \AA^{3}$, for $\mathbf{1}^{\prime}$ and $a=19.87(1) \AA$, $b=26.94(2) \AA, \quad c=19.36(1) \AA, \quad \alpha=103.66(7)^{\circ}, \quad \beta=$ $90.52(5)^{\circ}, \quad \gamma=94.76(7)^{\circ}$, and $V=10034(12) \AA^{3}$, were obtained from least-square refinement with 25 reflections. Three standard reflections were chosen and monitored with every 100 reflections and did not show any significant change. Total 3900 and 13876 reflections were measured for $\mathbf{1}^{\prime}$ and $\mathbf{4}$, respectively. The structure determination was performed described bellow.

For 1': The 474 observed reflections $(I>3 \sigma(I))$ were used for the refinement. The systematic absences uniquely led to monoclinic space group $P 2_{1} / n$. The structure was solved by Patterson method using the TEXSAN crystallographic software package of the Molecular Structure Corp. The coordinate of Mo was determined from Patterson map. Subsequent Fourier syntheses based on the phase of Mo determined four $\mathrm{S}$ atoms and a $\mathrm{P}$ atom. Unfortunately, the poor intensity of the reflections resulted in the lack of satisfactory electron density, therefore we tried to refine the orientation of the fixed structure of $\mathbf{1}^{\prime}$ which was assumed to be similar to the reported structure of $\left(\mathrm{PPh}_{4}\right)\left[\mathrm{Mo}^{\mathrm{V}} \mathrm{O}\left(\mathrm{S}-2-\mathrm{CH}_{3} \mathrm{CONH}\right.\right.$ $\left.\left.\mathrm{C}_{6} \mathrm{H}_{4}\right)_{4}\right] .{ }^{5}$ The cation and anions were located based on Patterson map $(R=34 \%)$. In this paper, a preliminary result of $\mathrm{X}$-ray analysis using a model colmplex, $\left(\mathrm{PPh}_{4}\right)\left[\mathrm{Mo}^{\mathrm{V}} \mathrm{O}\left(\mathrm{S}-2-\mathrm{CH}_{3} \mathrm{CONHC} \mathrm{H}_{4}\right)_{4}\right]$ is shown.

For 4. The 3744 observed reflections $(I>3 \sigma(I))$ were used for the refinement. Based on a statistical analysis of intensity distribution, and the successful solution and refinement of the structure, the space group was determined to be $\mathrm{P} \overline{1}$. Two anions and four cations are present in an asymmetric unit. The positions of Mo and Se were determined by direct method using the TEXSAN crystallographic software package of the Molecular Structure Corp. An empirical absorption correction based on azimuthal scans of several reflections was applied which resulted in transmission factors ranging from 0.74 to 1.00 . The terminal oxo ligand, phenyl rings, amide groups, and one of lauroyl chains and two cations were found in the differential map. Because the number and the intensities of reflections were very poor, we used a rigid group refinement. The rigid groups consist of three parts, $2-\mathrm{C}_{6} \mathrm{H}_{4} \mathrm{~N}, \mathrm{COC}$, and $\left(\mathrm{CH}_{2}\right)_{9} \mathrm{CH}_{3}$. The distances, $\mathrm{C}-\mathrm{C}=1.395 \AA$ (phenyl ring), $\mathrm{C}-\mathrm{N}=1.40 \AA$, $\mathrm{N}-\mathrm{C}(\mathrm{O})=1.35 \AA, \mathrm{C}-\mathrm{C}(\mathrm{O})=1.21$ and $\mathrm{C}-\mathrm{C}=1.50 \AA$ (laur-

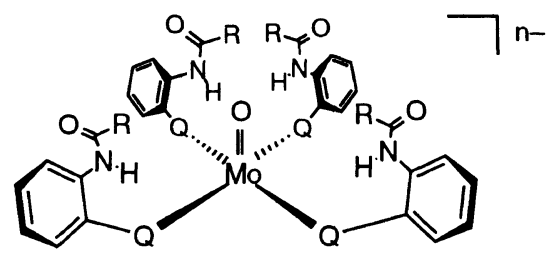

$$
\begin{aligned}
& \mathrm{n}=1 \\
& \mathrm{Q}=\mathrm{S}, \mathrm{R}=\left(\mathrm{CH}_{2}\right)_{10} \mathrm{CH}_{3} \quad 1\left(\mathrm{NEt}_{4}{ }^{+} \text {salt }\right) \\
& \mathrm{Q}=\mathrm{S}, \mathrm{R}=\mathrm{CH}_{3} \\
& 5 \\
& \mathrm{n}=2 \\
& \mathrm{Q}=\mathrm{S}, \mathrm{R}=\left(\mathrm{CH}_{2}\right)_{10} \mathrm{CH}_{3} \\
& \mathrm{Q}=\mathrm{S}, \mathrm{R}=\left(\mathrm{CH}_{2}\right)_{8}\left[\left(\mathrm{CH}_{2}\right)_{6} \mathrm{CH}_{3}\right] \mathrm{CH}_{3} \\
& Q=\mathrm{Se}, \mathrm{R}=\left(\mathrm{CH}_{2}\right)_{10} \mathrm{CH}_{3}
\end{aligned}
$$$$
1 \text { ' }\left(\mathrm{Ph}_{4} \mathrm{P}^{+} \text {salt }\right)
$$

Scheme 1.

yl) were used. The angles are $\mathrm{C}-\mathrm{N}-\mathrm{C}=130^{\circ}$ and $\mathrm{N}-\mathrm{C}-\mathrm{O}=123.5^{\circ}$. The $R$ and $R_{\mathrm{w}}$ factors converged to 0.172 and 0.248 , respectively including no hydrogen atoms. Atom scattering factors and dispersion corrections were taken from the International Table. ${ }^{18}$

\section{RESULTS AND DISCUSSION}

Bundling Conformation of $M o(I V)$ Complexes in Solution

The molybdenum(IV) complexes showed well-defined ${ }^{1} \mathrm{H}$ NMR signals due to low-spin $d^{2}$ configuration. As previously reported, conformations of these complexes in the solution are easily determined using ${ }^{1} \mathrm{H}$ NMR technique. Figure 1 shows ${ }^{1} \mathrm{H}$ NMR spectra of $\left(\mathrm{NEt}_{4}\right)_{2}$ $\left[\mathrm{Mo}^{\mathrm{IV}} \mathrm{O}\left(\mathrm{S}-2-\mathrm{RCONHC}_{6} \mathrm{H}_{4}\right)_{4}\right]\left(\mathrm{R}=\mathrm{CH}_{3}(5), \mathrm{CH}_{3}\left(\mathrm{CH}_{2}\right)_{10}\right.$ (2), $\mathrm{CH}_{3}\left(\mathrm{CH}_{2}\right)_{8}\left\{\mathrm{CH}_{3}\left(\mathrm{CH}_{2}\right)_{6}\right\} \mathrm{CH}$ (3)) in acetonitrile-d $d_{3}$ at $30^{\circ} \mathrm{C}$. The complex $5,\left(\mathrm{NEt}_{4}\right)_{2}\left[\mathrm{Mo}^{\mathrm{IV}} \mathrm{O}\left(\mathrm{S}-2-\mathrm{CH}_{3} \mathrm{CO}\right.\right.$ $\left.\left.\mathrm{NHC}_{6} \mathrm{H}_{4}\right)_{4}\right]$ shows so-called all-up conformer A established by X-ray analysis and ${ }^{1} \mathrm{H}$ NMR spectra. ${ }^{5}$ All acylamino groups are located on the same side against $\mathrm{S}_{4}$ plane and amide $\mathrm{NH}$ groups are faced to $\mathrm{Mo}=\mathrm{O}$ moiety. The conformation is suitable to form intramolecular $\mathrm{NH} \cdots \mathrm{S}$ hydrogen bond in solid and solution states. The presence of $\mathrm{NH} \cdots \mathrm{S}$ hydrogen bond has been established by X-ray and IR spectra in solid state. The amide $\mathrm{NH}$ stretching band, $v(\mathrm{NH})$, and $v(\mathrm{C}=\mathrm{O})$ are found at 3340 and $1689 \mathrm{~cm}^{-1}$, respectively. The intramolecularly $\mathrm{NH} \cdot \mathrm{S}$ hydrogen bonded $v(\mathrm{NH})$ and $v(\mathrm{C}=\mathrm{O})$ of $\left(\mathrm{NEt}_{4}\right)\left[\mathrm{Mo}^{\mathrm{v}} \mathrm{O}\left(\mathrm{S}-2-\mathrm{CH}_{3} \mathrm{CONHC}_{6} \mathrm{H}_{4}\right)_{4}\right]$ have been reported to be found at 3335 and $1686 \mathrm{~cm}^{-1}$, respectively. In acetonitrile- $d_{3}$ solution, the $\mathrm{NH}$ proton signals are found at $8.7-9.7 \mathrm{ppm}$. Especially, the $\mathrm{NH}$ protons located close to $\mathrm{Mo}=\mathrm{O}$ bond are observed at the lower field due to deshielding effect of $\mathrm{Mo}=\mathrm{O}$ bond which has a triple bond character as expressed in the acetylene-like structure, $\mathrm{Mo}^{\delta-} \equiv \mathrm{O}^{\delta+}$. A small amount of conformational isomer of $\left(\mathrm{NEt}_{4}\right)_{2}\left[\mathrm{Mo}^{\mathrm{IV}} \mathrm{O}\left\{\mathrm{S}-o-\mathrm{CH}_{3}\right.\right.$ $\left.\left.\left(\mathrm{CH}_{2}\right)_{8}\left[\mathrm{CH}_{3}\left(\mathrm{CH}_{2}\right)_{6}\right] \mathrm{CHCONHC}{ }_{6} \mathrm{H}_{4}\right\}_{4}\right]$ having alternating arrangement of acylamino groups, up-down-updown, or up-up-down-down (B) is present as shown in Figure 1. The acylamino groups directed to the down side are assignable by the characteristic higher field shifted NH protons due to less influence of the de- 

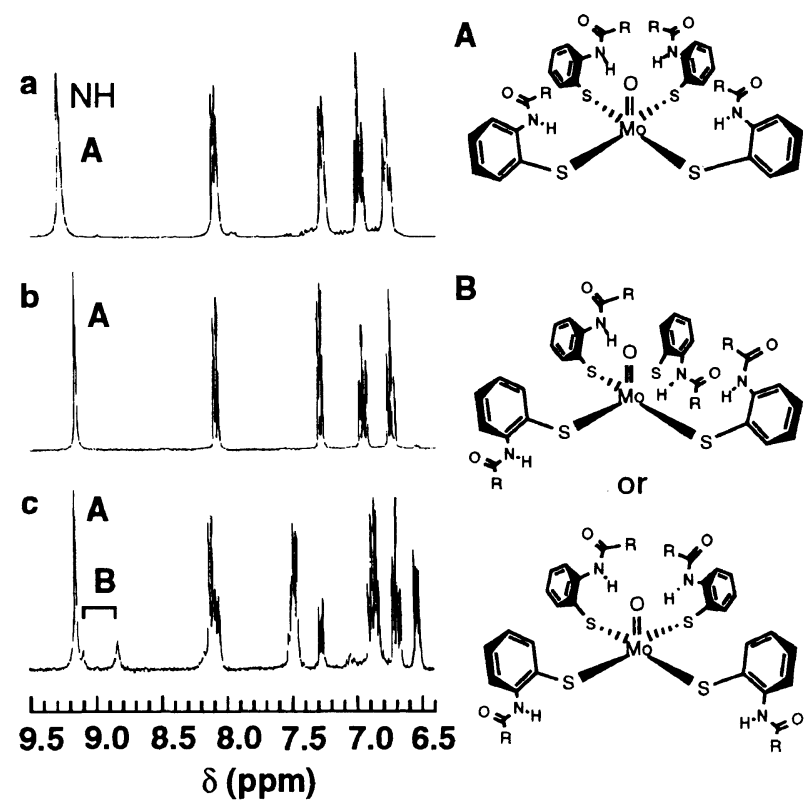

Figure 1. ${ }^{1} \mathrm{H}$ NMR spectra of $\left(\mathrm{NEt}_{4}\right)_{2}\left[\mathrm{Mo}^{\mathrm{IV}} \mathrm{O}\left(\mathrm{S}-2-\mathrm{RCONHC}_{6} \mathrm{H}_{4}\right)_{4}\right]$ $\left(\mathrm{R}=\mathrm{CH} 3\right.$ (a), $\mathrm{CH}_{3}(\mathrm{CH} 2)_{10}$ (b), $\mathrm{CH}_{3}\left(\mathrm{CH}_{2}\right)_{8}\left[\mathrm{CH}_{3}\left(\mathrm{CH}_{2}\right)_{6}\right] \mathrm{CH}$ (c)) in acetonitrile- $d_{3}$ at $30^{\circ} \mathrm{C}$.

shielding effect of $\mathrm{Mo}=\mathrm{O}$ bond. The integral intensities of these protons are $1: 1$ ratio which indicate that two of the four acylamino groups are directed to down side. The minor conformer is suitable to prevent a steric congestion between the branched chains that are more bulky than a linear methylene chain, lauryl. On the other hand, the complex 2 indicated a simple ${ }^{1} \mathrm{H}$ NMR spectrum with a narrow line width due to the restricted conformation. The $T_{1}$ values for aromatic protons of $\mathbf{2}$ are in the range of $2-3 \mathrm{~s}$, which are about three times for those of 1 . These results suggest that the orientated long hydrocarbon chains interact each other by van der Waals interaction which limits the conformational motion. The orientation is preferable to construct a layered supramolecular structure in the solid state as has been found for many organic and inorganic compounds with aliphatic chains.

\section{Micellization and Stability}

The complexes having hydrocarbon chains show good solubility in non-polar solvents despite of its essentially ionic character that is preferable to dissolve them in polar solvents. Especially complex $\mathbf{1}$ is soluble in a mixture of diethyl ether and acetonitrile although the complex exhibits poor solubility individually in either pure diethyl ether or acetonitrile. This behavior indicates the amphoteric character as found for micelles. The ionic part around metal center has good affinity to polar solvent such as acetonitrile. On the contrary, the hydrocarbon chains of the complex have good solubility in non-polar solvent such as diethyl ether.

The orientation of hydrocarbon chains is favorable for interaction with hydrophobic surface. Figure 2 illustrates the interaction between hydrocarbon chains of the complex and the hydrophobic interface of micelle (Triton $\mathrm{X}-100)$. The hydrophobic environment stabilizes the complex against hydrolysis. The complexes 1 and 4 are relatively stable in aqueous micellar solution compared

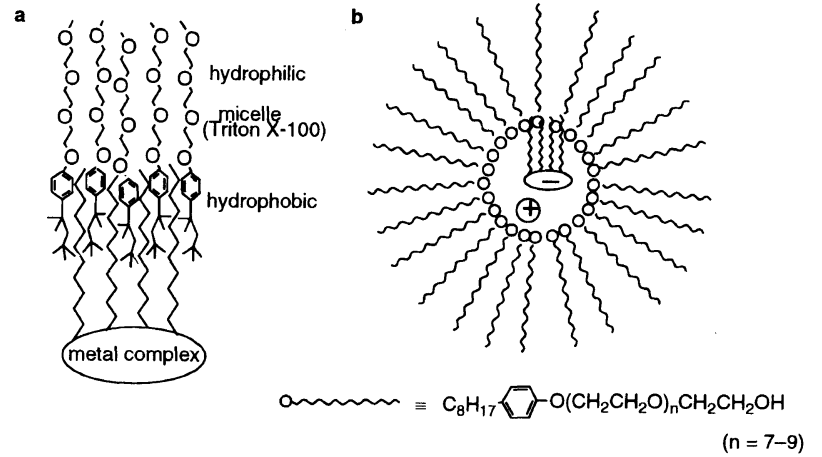

Figure 2.Schematic drawing of a) interaction of $\left(\mathrm{NEt}_{4}\right)\left[\mathrm{Mo}^{\mathrm{V}} \mathrm{O}\{\mathrm{S}-2-\right.$ $\left.\left.\mathrm{CH}_{3}\left(\mathrm{CH}_{2}\right)_{10} \mathrm{CONHC}_{6} \mathrm{H}_{4}\right\}_{4}\right]$ with Triton $\mathrm{X}-100$ in micelle and $\left.\mathrm{b}\right)$ the complex in the micelle.

with the corresponding derivatives without hydrocarbon chains. The stability could be monitored with characteristic absorption due to $\mathrm{Mo}^{\mathrm{V}} \mathrm{OS}_{4}$ or $\mathrm{Mo}^{\mathrm{IV}} \mathrm{OSe}_{4}$ core. Although the intense absorption of $\pi-\pi^{*}$ transition of aromatic ring of Triton X-100 masks absorption of the complex in UV region, characteristic ligand to metal charge transfer (LMCT) bands of 1 could be observed at $537 \mathrm{~nm}\left(3300 \mathrm{M}^{-1} \mathrm{~cm}^{-1}\right)$ and $640 \mathrm{~nm}\left(2200 \mathrm{M}^{-1}\right.$ $\left.\mathrm{cm}^{-1}\right)$ in acetonitrile and $530 \mathrm{~nm}\left(2800 \mathrm{M}^{-1} \mathrm{~cm}^{-1}\right)$ and $630 \mathrm{~nm}\left(1500 \mathrm{M}^{-1} \mathrm{~cm}^{-1}\right)$ in aqueous micellar solution. The LMCT band for $\left(\mathrm{NEt}_{4}\right)\left[\mathrm{Mo}^{\mathrm{V}} \mathrm{O}\left(\mathrm{S}-\mathrm{o}-\mathrm{CH}_{3} \mathrm{CONHC}_{6}\right.\right.$ $\left.\left.\mathrm{H}_{4}\right)_{4}\right]$ has been reported at $540 \mathrm{~nm}\left(2300 \mathrm{M}^{-1} \mathrm{~cm}^{-1}\right)$ and $640 \mathrm{~nm}\left(1800 \mathrm{M}^{-1} \mathrm{~cm}^{-1}\right)$ in acetonitrile. ${ }^{5}$ These spectra roughly resemble each other but the relative intensity at $c a .540 \mathrm{~nm}$ compared with that at $c a .640 \mathrm{~nm}$ is different. The relative intensity varies depending on the substituent and the solvent. The complex containing bulky $t$-butyl groups, $\left[\mathrm{Mo}^{\mathrm{V}} \mathrm{O}\left(\mathrm{S}-2-t \text { - } \mathrm{BuCONHC}{ }_{6} \mathrm{H}_{4}\right)_{4}\right]^{-}$, exhibits absorption maxima at $541 \mathrm{~nm}\left(4000 \mathrm{M}^{-1} \mathrm{~cm}^{-1}\right)$ and $650 \mathrm{~nm}\left(2000 \mathrm{M}^{-1} \mathrm{~cm}^{-1}\right)$ in acetonitrile. The relative intensity at $541 \mathrm{~nm}$ increases in DME (1,2-dimethoxyethane). Because the solvent-dependent change of the relative intensity is also observed for $\left[\mathrm{Mo}^{\mathrm{v}} \mathrm{O}(\mathrm{S}-2-\right.$ $\left.\left.\mathrm{CH}_{3} \mathrm{CONHC}_{6} \mathrm{H}_{4}\right)_{4}\right]^{-}$, it is not caused by the abundance of the two isomers as found for $\left[\mathrm{Mo}^{\mathrm{v}} \mathrm{O}(\mathrm{S}-2-t-\right.$ $\left.\left.\mathrm{BuCONHC}_{6} \mathrm{H}_{4}\right)_{4}\right]^{-5}$. The difference of the absorption spectra between 1 and $\left[\mathrm{Mo}^{\mathrm{v}} \mathrm{O}\left(\mathrm{S}-2-\mathrm{CH}_{3} \mathrm{CONHC}_{6} \mathrm{H}_{4}\right)_{4}\right]^{-}$ and the spectral change depending on solvent suggest variation of environment around the metal ion, which is ascribed to hydrophobic circumstance made by the long hydrocarbon chains.

The Mo(IV) complex 4 showed a characteristic band at $554 \mathrm{~nm}\left(200 \mathrm{M}^{-1} \mathrm{~cm}^{-1}\right)$ and $331 \mathrm{~nm}\left(13000 \mathrm{M}^{-1}\right.$ $\left.\mathrm{cm}^{-1}\right)$ in acetonitrile and $565 \mathrm{~nm}\left(300 \mathrm{M}^{-1} \mathrm{~cm}^{-1}\right)$ and $330 \mathrm{~nm}\left(9000 \mathrm{M}^{-1} \mathrm{~cm}^{-1}\right)$ in aqueous micellar solution due to $\mathrm{d}-\mathrm{d}$ and LMCT band, respectively. The spectroscopic similarity indicates the stability in aqueous micellar solution without hydrolysis. In the same way, a thiolate complex, $\left(\mathrm{NEt}_{4}\right)_{2}\left[\mathrm{Mo}^{\mathrm{IV}} \mathrm{O}\left\{\mathrm{S}-2-\mathrm{CH}_{3}\left(\mathrm{CH}_{2}\right)_{10}\right.\right.$ $\left.\left.\mathrm{CONHC}_{6} \mathrm{H}_{4}\right\}_{4}\right]$, exhibits a d-d transition at $537 \mathrm{~nm}$ $\left(360 \mathrm{M}^{-1} \mathrm{~cm}^{-1}\right)$ and a LMCT band at $299 \mathrm{~nm}$ $\left(25000 \mathrm{M}^{-1} \mathrm{~cm}^{-1}\right)$, which is the typical spectral pattern of $\left[\mathrm{Mo}^{\mathrm{IV}} \mathrm{O}(\mathrm{SAr})_{4}\right]^{2-}(\mathrm{SAr}=$ arenethiolate $)$. The similarity supports the prediction from the ${ }^{1} \mathrm{H}$ NMR spectral data as described above.

Figure 3 shows quasireversible redox couples of the complexes in aqueous micellar solution and acetonitrile. 
a

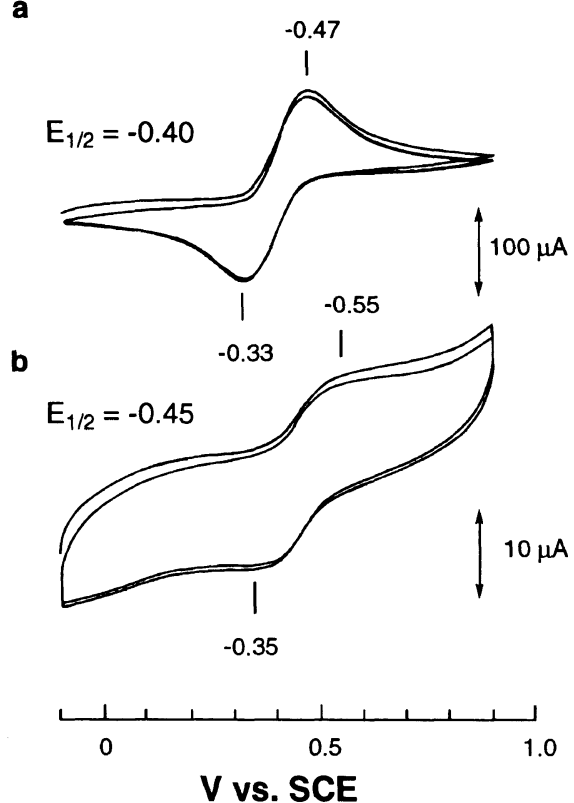

c

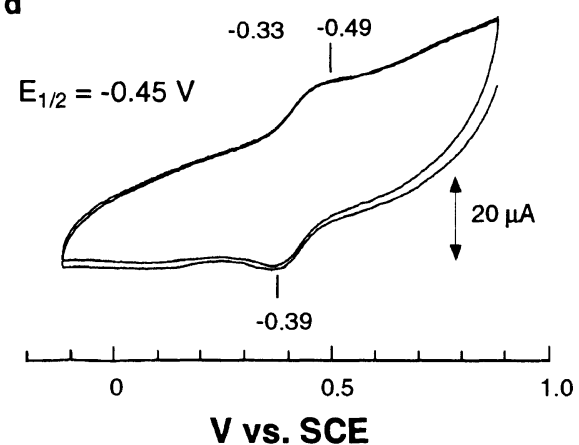

Figure 3. Cyclic voltammograms of $\left(\mathrm{NEt}_{4}\right)\left[\mathrm{Mo}^{\mathrm{v}} \mathrm{O}\left\{\mathrm{S}-2-\mathrm{CH}_{3}\left(\mathrm{CH}_{2}\right)_{10} \mathrm{CONHC} \mathrm{CH}_{4}\right\}_{4}\right](\mathbf{1})$ a) in acetonitrile and b) in aqueous micellar solution and $\left.\left(\mathrm{NEt}_{4}\right)_{2}\left[\mathrm{Mo}^{\mathrm{IV}} \mathrm{O}\left\{\mathrm{Se}-2-\mathrm{CH}_{3}\left(\mathrm{CH}_{2}\right)_{10} \mathrm{CONHC}_{6} \mathrm{H}_{4}\right\}_{4}\right](4) \mathrm{c}\right)$ in acetonitrile and d) in aqueous micellar solution.

The redox potentials of $1(-0.40 \mathrm{~V}$ in acetonitrile, $-0.45 \mathrm{~V}$ in aqueous micellar solution) are more positive than that $(-0.81 \mathrm{~V}$ in acetonitrile) of the non-substituted benzenethiolate complex, $\left(\mathrm{NEt}_{4}\right)\left[\mathrm{Mo}^{\mathrm{v}} \mathrm{O}(\mathrm{SPh})_{4}\right]$; the effect of $\mathrm{NH} \cdots \mathrm{S}$ hydrogen bonds has been discussed in the literature. ${ }^{5}$ The small current of the redox couple in micellear solution was caused by the difficulty of access of the complex surrounded by micelle to electrode. However, the reversible redox reaction occurred successfully without decomposition of the complex. Thus, a stable $\mathrm{Mo}(\mathrm{V}) / \mathrm{Mo}(\mathrm{IV})$ redox state is considered to be established in aqueous micellar solution. The redox potential of $\left(\mathrm{NEt}_{4}\right)_{2}\left[\mathrm{Mo}^{\mathrm{IV}} \mathrm{O}\left\{\mathrm{S}-2-\mathrm{CH}_{3}\left(\mathrm{CH}_{2}\right)_{8}\left[\mathrm{CH}_{3}\right.\right.\right.$ $\left.\left.\left.\left(\mathrm{CH}_{2}\right)_{6}\right] \mathrm{CHCONHC}_{6} \mathrm{H}_{4}\right\}_{4}\right]$ was found at $-0.46 \mathrm{~V}$ vs. saturated calomel electrode (SCE) in acetonitrile. The $\mathrm{Mo}^{\mathrm{V}} / \mathrm{Mo}^{\mathrm{IV}}$ redox couples of $\mathbf{4}$ was observed at $-0.38 \mathrm{~V}$ in acetonitrile and $-0.45 \mathrm{~V}$ in aqueous micellar solution. The redox potential of the selenophenolate derivative was found at more positive point in comparison with the corresponding thiolate derivative.

\section{Stabilization by Long Hydrocarbon Chains}

Hydrolysis of the $\mathrm{Mo}(\mathrm{V})$ complexes was performed to estimate the stability induced by long hydrocarbon chains. The logarithmic plot for the decay curve of $\left(\mathrm{NEt}_{4}\right)\left[\mathrm{Mo}^{\mathrm{V}} \mathrm{O}\left\{\mathrm{S}-2-\mathrm{CH}_{3}\left(\mathrm{CH}_{2}\right)_{10} \mathrm{CONHC}_{6} \mathrm{H}_{4}\right\}_{4}\right]$ (1) and $\left(\mathrm{NEt}_{4}\right)\left[\mathrm{Mo}^{\mathrm{v}} \mathrm{O}\left(\mathrm{S}-2-\mathrm{CH}_{3} \mathrm{CONHC}_{6} \mathrm{H}_{4}\right)_{4}\right](5)$ in a mixture of acetonitrile and water $(10: 1, \mathrm{v} / \mathrm{v})$ is shown in Figure 4. The low linearity is caused by the formation of decomposition product with an absorption in visible region. Mono-oxomolybdenum(V) thiolate complexes have been reported to be converted to $\mu$-oxo ${ }^{19}$ or $\mu$-alkoxo binuclear complexes ${ }^{17,20-22}$ in the presence of water or alcohol. The binuclear complexes exhibit absorption in the visible region, e.g., $\left[\mathrm{Mo}_{2} \mathrm{O}_{2}(\mathrm{SPh})_{6}\right.$ $(\mathrm{OMe})]^{-}$exhibits a shoulder at $505 \mathrm{~nm} .^{21}$ The reaction has been considered to proceed with the dissociation of benzenethiolate ligand. In the initial stage of the reaction, the pseudo-first order rate constant is

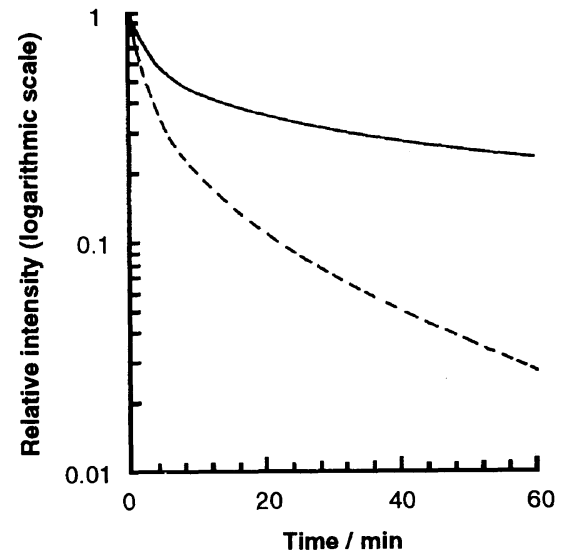

Figure 4. The decay curve of $\left(\mathrm{NEt}_{4}\right)\left[\mathrm{Mo}{ }^{\mathrm{v}} \mathrm{O}\left\{\mathrm{S}-2-\mathrm{CH}_{3}\left(\mathrm{CH}_{2}\right)_{10} \mathrm{C}\right.\right.$ $\left.\left.\mathrm{ONHC}_{6} \mathrm{H}_{4}\right\}_{4}\right](\mathbf{1})(-)$ and $\left(\mathrm{NEt}_{4}\right)\left[\mathrm{Mo}^{\mathrm{v}} \mathrm{O}\left(\mathrm{S}-2-\mathrm{CH}_{3} \mathrm{CONHC}_{6} \mathrm{H}_{4}\right)_{4}\right](5)$ $(--)$ by hydrolysis in a mixture $(10: 1, \mathrm{v} / \mathrm{v})$ of acetonitrile and water, which was detected with absorbance at $540 \mathrm{~nm}$.

estimated as $2 \times 10^{-3} \mathrm{~s}^{-1}$ for $\mathbf{1}$ and $5 \times 10^{-3} \mathrm{~s}^{-1}$ for 5 . In the range of $20-60 \mathrm{~min}$, the value is estimated as $2 \times 10^{-4} \mathrm{~s}^{-1}$ for 1 and $6 \times 10^{-4} \mathrm{~s}^{-1}$ for 5 , respectively. At the point after $60 \mathrm{~min}$, all the absorption of $5 \mathrm{di}$ sappeared but $23 \%$ of the absorption of 1 still remained. Thus, the long hydrocarbon chains prevent the hydrolysis with a half or less rate constant of the complex containing acetyl groups.

\section{Supramolecular Structure in Solid State}

The complexes $\mathbf{1}^{\prime}$ and $\mathbf{4}$ were readily crystallized to give big plates enough to determine their cell parameters by a single crystal X-ray analysis. Unfortunately the crystals exhibit too weak reflections to determine the molecular structure in detail, however, the poor observed reflections revealed the unique supramolecular structure of these complexes. The crystal packing of $\mathbf{1}^{\prime}$ and 4 is shown in Figure 5. For the structure of $\mathbf{1}^{\prime}$ and $\mathbf{4}$, the methylene groups were placed as ideal trans-zigzag conformation. In general, the conformation of methylene 
T. OKamura et al.

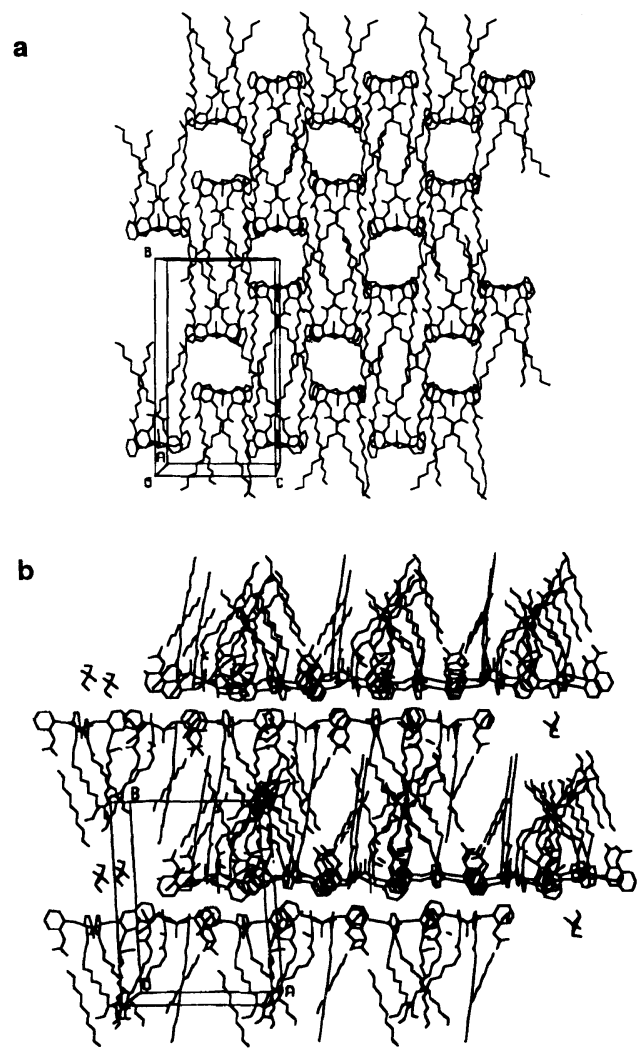

Figure 5. The arrangements of a) packing $\left[\mathrm{Mo}^{\mathrm{v}} \mathrm{O}\left\{\mathrm{S}-2-\mathrm{CH}_{3}\left(\mathrm{CH}_{2}\right)_{10}\right.\right.$ $\left.\left.\mathrm{CONHC}_{6} \mathrm{H}_{4}\right\}_{4}\right]^{-}$anions of $\mathbf{1}^{\prime}$ and b) packing $\left(\mathrm{NEt}_{4}\right)_{2}\left[\mathrm{Mo}^{\mathrm{IV}} \mathrm{O}\{\mathrm{Se}-2-\right.$ $\left.\left.\mathrm{CH}_{3}\left(\mathrm{CH}_{2}\right)_{10} \mathrm{CONHC} \mathrm{H}_{4}\right\}_{4}\right]$ in the crystal.
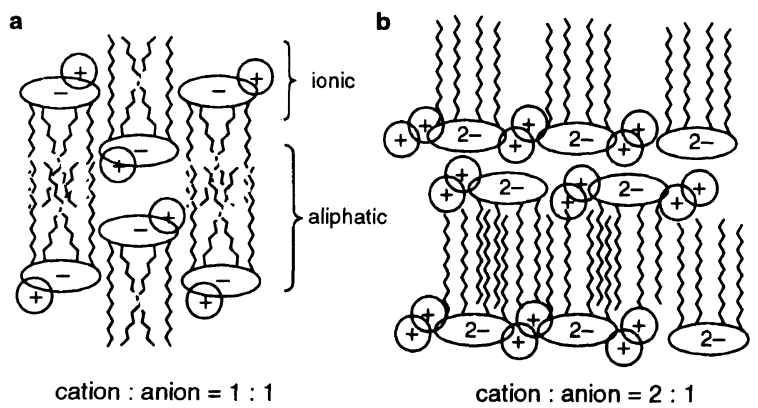

Figure 6. Schematic drawing of crystal packing of a) $\left(\mathrm{PPh}_{4}\right)\left[\mathrm{Mo}^{\mathrm{v}}\right.$ $\left.\mathrm{O}\left\{\mathrm{S}-2-\mathrm{CH}_{3}\left(\mathrm{CH}_{2}\right)_{10} \mathrm{CONHC}_{6} \mathrm{H}_{4}\right\}_{4}\right]\left(\mathbf{1}^{\prime}\right)$ and b) $\left(\mathrm{NEt}_{4}\right)_{2}\left[\mathrm{Mo}^{\mathrm{IV}} \mathrm{O}\{\mathrm{Se}-\right.$ $\left.\left.2-\mathrm{CH}_{3}\left(\mathrm{CH}_{2}\right)_{10} \mathrm{CONHC}_{6} \mathrm{H}_{4}\right\}_{4}\right]$ (4).

chain is assignable by the characteristic IR bands including deformation vibrations. ${ }^{23,24}$ In the IR spectra of compound $\mathbf{1}^{\prime}$, the signals in the region between 1000 and $1400 \mathrm{~cm}^{-1}$ were overlapped with the other vibration modes arising from the acylaminophenyl group, e.g., $\mathrm{CN}$ bond stretching, thus we could not determine the real conformations of the chains.

The intermolecular interaction causes facility in crystallization. Such a long hydrocarbon chain has been found as an extended form in the crystal of organic ${ }^{25-27}$ and copper(II) compounds with phenanthrene or pyridine coordination which form molecular laminates. ${ }^{8}$ A schematic drawing of packing for these molecules is shown in Figure 6. These supramolecular structures are significantly different each other. The packing remarkably depends on the molecular structure of constituent ions and the ratio of anion and cation. The structure of

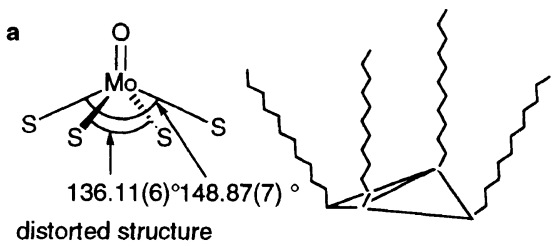

b

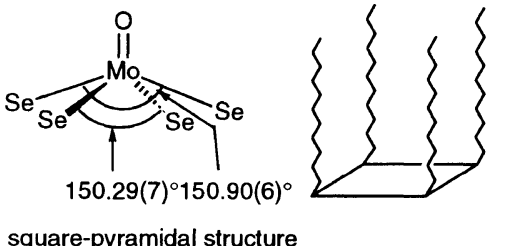

Figure 7. Comparison of $\mathrm{Mo}^{\mathrm{v}} \mathrm{OS}_{4}$ with $\mathrm{Mo}^{\mathrm{IV}} \mathrm{OSe}_{4}$ cores. a) $\mathrm{Mo}^{\mathrm{v}} \mathrm{OS}_{4}$ core of $\left(\mathrm{PPh}_{4}\right)\left[\mathrm{Mo}^{\mathrm{v}} \mathrm{O}\left(\mathrm{S}-2-\mathrm{CH}_{3} \mathrm{CONHC} \mathrm{H}_{4}\right)_{4}\right]$ and the molecular structure of $\left[\mathrm{Mo}^{\mathrm{v}} \mathrm{O}\left\{\mathrm{S}-2-\mathrm{CH}_{3}\left(\mathrm{CH}_{2}\right)_{10} \mathrm{CONHC}_{6} \mathrm{H}_{4}\right\}_{4}\right]^{-}$, where the plane shows the geometry of $\mathrm{MoO}\left(\mathrm{SC}_{6} \mathrm{H}_{4} \mathrm{X}\right)_{4}{ }^{-}$moiety $\left(\mathrm{X}=\mathrm{CH}_{3}\right.$ $\left.\left(\mathrm{CH}_{2}\right)_{10} \mathrm{CONH}\right)$ and zigzag chain indicate the acylamino group. b) $\mathrm{Mo}^{1 \mathrm{~V}} \mathrm{OSe} 4$ core of $\left(\mathrm{PPh}_{4}\right)_{2}\left[\mathrm{Mo}^{\mathrm{IV}} \mathrm{O}\left(\mathrm{Se}-2-\mathrm{CF}_{3} \mathrm{CONHC}_{6} \mathrm{H}_{4}\right)_{4}\right]$ and the corresponding molecular structure of $\left[\mathrm{Mo}{ }^{\mathrm{IV}} \mathrm{O}\left\{\mathrm{Se}-2-\mathrm{CH}_{3}\left(\mathrm{CH}_{2}\right)_{10}\right.\right.$ $\left.\mathrm{CONHC}_{6} \mathrm{H}_{4} i_{4}\right]^{2}$

anion part especially around the molybdenum center is largely different between $\mathrm{Mo}^{\mathrm{v}} \mathrm{S}_{4}$ and $\mathrm{Mo}^{\mathrm{IV}} \mathrm{Se}_{4}$ cores based on the $\mathrm{X}$-ray structure of the small molecules, $\left(\mathrm{PPh}_{4}\right)\left[\mathrm{Mo}^{\mathrm{v}} \mathrm{O}\left(\mathrm{S}-o-\mathrm{CH}_{3} \mathrm{CONHC}_{6} \mathrm{H}_{4}\right)_{4}\right] \cdot \mathrm{CH}_{3} \mathrm{CN}$ and $\left(\mathrm{PPh}_{4}\right)_{2}\left[\mathrm{Mo}^{\mathrm{IV}} \mathrm{O}\left(\mathrm{Se}-\mathrm{o}-\mathrm{CF}_{3} \mathrm{CONHC}_{6} \mathrm{H}_{4}\right)_{4}\right] .^{5,28}$

Comparison between square-pyramidal $\mathrm{Mo}^{\mathrm{IV}} \mathrm{OSe}_{4}$ and $\mathrm{Mo}^{\mathrm{V}} \mathrm{OS}_{4}$ cores is summarized in Figure 7. The distance of $\mathrm{Mo}^{\mathrm{IV}}-\mathrm{Se}$ bond (mean $2.523 \AA$ ) is longer than $\mathrm{Mo}^{\mathrm{v}}-\mathrm{S}$ bond (mean $2.397 \AA$ ) by $0.126 \AA$. Difference between the two diagonal Se-Mo-Se angles is very small $\left(0.61^{\circ}\right)$ which means its highly axial symmetrical $\mathrm{MoOSe}_{4}$ core about Mo-O axis and shows co-planarity of the four Se atoms. On the contrary, the large difference $\left(12.76^{\circ}\right)$ between two S-Mo-S angles indicates the distorted square-pyramidal $\mathrm{MoOS}_{4}$ core toward trigonal-bipyramidal geometry as described in the literature. ${ }^{5}$

The amide and benzene ring are found in almost the same plane and the S-C torsion angle is limited by the steric hindrance of the arene group. Thus the degree of the bending of $\mathrm{S}_{4}$ plane as illustrated in Figure 7 is a predominant factor to determine the orientation of hydrocarbon chains adjacent to the amide plane. The coplanarity found in $\mathrm{Mo}^{\mathrm{IV}} \mathrm{OSe}_{4}$ core permitted such an arrangement of hydrocarbons and layered supramolecular structure. The bent geometry of $\mathrm{Mo}^{\mathrm{v}} \mathrm{OS}_{4}$ core forces the chains to separate each other. Such disordered chains cannot obtain sufficient stablilization energy by van der Waals interaction in layered structure. The total charge of ions or the ratio of the number of cation to anion also largely contributes to electrostatic, hydrophobic and steric interaction and the resultant packing of molecules, i.e., supramolecular structure.

\section{CONCLUSION}

The complexes make a hydrophobic circumstance using hydrocarbon chains which prevents from the attack of water and thus obtain its stability in aqueous media. The complexes also exhibit a stable $\mathrm{Mo}(\mathrm{V}) / \mathrm{Mo}(\mathrm{IV})$ redox 
couple in aqueous micellar solution, which simulates the environment inside of metalloproteins.

The unique molybdenum(IV, V) thiolate and selenolate with bundling long hydrocarbon chains presented a new concept of the construction of supermolecules. The supermolecular structure is determined by the geometry of $\mathrm{MoOQ}_{4}(\mathrm{Q}=\mathrm{S}, \mathrm{Se})$ core depending on the oxidation state of metal ion and radius of the coordinated atom. This new strategy to construct supramolecules is useful to develop redox active supramolecules involving metal ion which are considered to be a promising candidate with electronic and magnetic characteristics.

\section{REFERENCES}

1. M. Lieberman and T. Sasaki, J. Am. Chem. Soc., 113, 1470 (1991).

2. M. R. Ghadiri, C. Soares, and C. Choi, J. Am. Chem. Soc., 114, 825 (1992).

3. M. R. Ghadiri, C. Soares, and C. Choi, J. Am. Chem. Soc., 114, 4000 (1992)

4. T. Sasaki and E. T. Kaiser, J. Am. Chem. Soc., 111, 380 (1989).

5. N. Ueyama, T. Okamura, and A. Nakamura, J. Am. Chem. Soc., 114, 8129 (1992)

6. J. S. Nowick and J. S. Chen, J. Am. Chem. Soc., 114, 1107 (1992).

7. Y. Ishikawa and T. Kunitake, J. Am. Chem. Soc., 113, 621 (1991).

8. F. M. Menger, J.-J. Lee, and K. S. Hagen, J. Am. Chem. Soc., 113, 4017 (1991).

9. M. J. Baena, J. Barberá, P. Espinet, A. Ezurra, M. B. Ros, and J. L. Serrano, J. Am. Chem. Soc., 116, 1899 (1994).

10. S. A. Hudson and P. M. Maitlis, Chem. Rev., 93, 861 (1993).

11. D. V. Baxter, R. H. Cayton, M. H. Chisholm, J. C. Huffman, E.
F. Putilina, S. L. Tagg, J. L. Weseman, J. W. Zwanaziger, and F. D. Darrington, J. Am. Chem. Soc., 116, 4551 (1994).

12. K. Ohta, T. Watanabe, T. Fujimoto, and I. Yamamoto, J. Chem. Soc., Chem. Commun., 1611 (1989)

13. J. Lahiri, G. D. Fate, S. B. Ungashe, and J. T. Groves, J. Am. Chem. Soc., 118, 2347 (1996).

14. A. Serrette, P. J. Carroll, and T. M. Swager, J. Am. Chem. Soc., 114, 1887 (1992).

15. M. Seiler, H. Dürr, I. Willner, E. Joselevich, A. Doron, and J.F. Stoddart, J. Am. Chem. Soc., 116, 3399 (1994).

16. S. Keimatsu and I. Satoda, J. Pharm. Soc., Jpn., 56, 600 (1936).

17. I. W. Boyd, I. G. Dance, K. S. Murray, and A. G. Wedd, Aust. J. Chem., 31, 279 (1978).

18. D. T. Cromer, "International Tables for X-ray Crystallography," The Kynoch Press, Birmingham, England, 1974.

19. R. D. Taylor, J. P. Street, M. Minell, and J. T. Spence, Inorg. Chem., 17, 3207 (1978)

20. I. Buchaman, W. Clegg, C. D. Garner, and G. M. Sheldrick, Inorg. Chem., 22, 3657 (1983).

21. G. R. Hanson, A. A. Brunette, A. C. Mcnell, K. S. Murray, and A. G. Wedd, J. Am. Chem. Soc., 103, 1953 (1981).

22. I. E. Dance, A. G. Wedd, and I. W. Boyd, Aust. J. Chem., 31, 519 (1978).

23. H. Hagemann, H. L. Strauss, and R. G. Snyder, Maclomolecules, 20, 2810 (1987)

24. R. G. Snyder, J. Chem. Phys., 47, 1316 (1967).

25. K. Okuyama, H. Watanabe, M. Shimomura, K. Hirabayashi, T. Kunitake, T. Kajiyama, and N. Yasuoka, Bull. Chem. Soc. Jpn., 59, 3351 (1986).

26. I. Pascher, S. Sundell, and H. Hauser, J. Mol. Biol., 153, 807 (1981).

27. P. B. Hitchcock, R. Mason, K. M. Thomas, and G. G. Shipley, Proc. Natl. Acad. Sci. U.S.A., 71, 3036 (1974).

28. T. Okamura, K. Taniuchi, N. Ueyama, and A. Nakamura, to be submitted. 